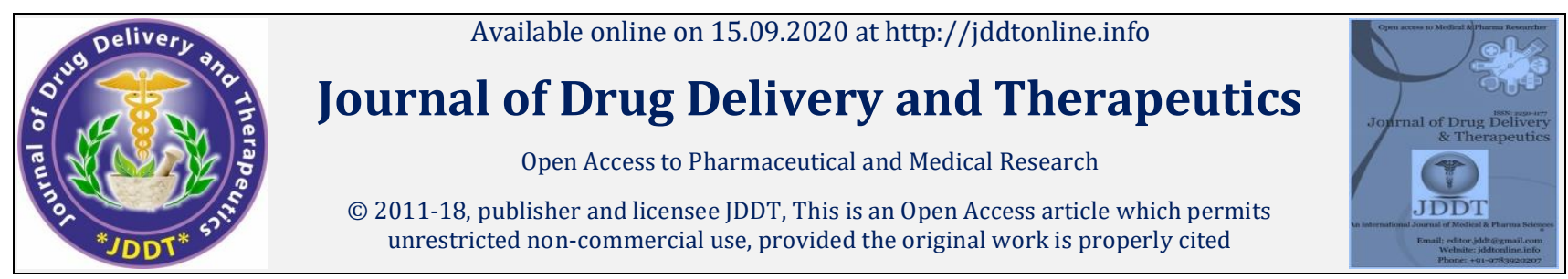

Open $\odot$ Access

Research Article

\title{
Annual study of Leptocybe invasa gall's number Fisher \& La Salle 2004 (Hymenoptera: Eulophidae) of Eucalyptus camaldulensis (Myrtaceae) in the North-East of Algeria
}

\author{
Abdelmalek Oulmi ${ }^{*}$, Noureddine Laadel ${ }^{2}$, Farida Benia ${ }^{2}$, Sofiane Guettaf ${ }^{3}$ \\ 1 Department of Ecology and Vegetal Biology, Laboratory for the Valorization of Natural Biological Resources (LVNBR), Faculty of Nature and \\ Life Science (FNLS), Ferhat ABBAS University Sétif-1, 19000 Setif, Eastern of Algeria \\ 2 University Ferhat Abbas Sétif-1, Faculty of Nature and Life Sciences, Department of Biology and Animal Physiology, Laboratory ADPVA, Setif-1, \\ Algeria \\ 3 Laboratory of Applied Microbiology, Faculty of Natural and Life Sciences, University Ferhat Abbas Sétif1, Setif, Algeria
}

\begin{abstract}
Eucalyptus camaldulensis is an essence of the family Myrtaceae. It resists a certain salt content and the sea wind. Despite that, it subject to many factors of degradation as parasitic and harmful insects. In the last years, an insect is detected on the foliage of Eucalyptus camaldulensis trees in Algeria (North-East region). The results made it possible evidence the presence of one harmful species Leptocybe invasa Fisher \& La Salle 2004 (Hymenoptera: Eulophidae), this parasite has been detected in 2006, The Chronology of Gall's emergence of Leptocybe invasa and its field infestation rate were followed since 2010, in Eucalyptus plantation in the North-East Region. Some statistical methods of Gall's emergence of this pest is reviewed and discussed. First, after exploration, we selected the most affected trees, second, we organized the samples of each tree, we respected the orientation (North-South-East-West). For each study site 10 trees were marked. 30 leaves of each tree were removed, so it is 300 leaves for each site, which were analyzed. We used the method of time series that connects the time with the number of galls. This study is based on the number of galls observed, on both sides of the leaves. In order to highlight the degree of attack of pests. The outputs were made from October 2012 to October 2013, due to two outputs per month.
\end{abstract}

Keywords: Eucalyptus, gall wasps, Eulophidae, gall inducers, Algeria.

Article Info: Received 08 July 2020; Review Completed 19 Aug 2020; Accepted 28 August 2020; Available online 15 September 2020

Cite this article as:

Oulmi A, Laadel N, Benia F, Guettaf S, Annual study of Leptocybe invasa gall's number Fisher \& La Salle 2004

(Hymenoptera: Eulophidae) of Eucalyptus camaldulensis (Myrtaceae) in the North-East of Algeria, Journal of Drug Delivery and Therapeutics. 2020; 10(5):94-97 http://dx.doi.org/10.22270/jddt.v10i5.4384

*Address for Correspondence:

Abdelmalek Oulmi, Department of Ecology and Vegetal Biology, Laboratory for the Valorization of Natural Biological Resources (LVNBR), Faculty of Nature and Life Science (FNLS), Ferhat ABBAS University Sétif-1, 19000 Setif, Eastern of Algeria

\section{INTRODUCTION}

The Eucalyptus camaldulensis is a species of the family Myrtaceae. Robust, resistant, native to Australia, E. camaldulensis has the widest distribution in Australia ${ }^{1}$.

The Eucalyptus has been among the most widely used and successful plantation trees. Only a few 500 species have potential in industrial plantations ${ }^{2}$. The Eucalyptus is the most introduced as reforestation species in several parts of the world.

Introduced in Algeria to clean swamps, Eucalyptus, by their rapid growth, their high efficiency, their easy operation, their plasticity with regard to the climate and adaptation to poor soils still were among the most used species. They gave excellent results in bioclimatic sub-humid and semi-arid, mainly below $800 \mathrm{~m}$ above the sea level and in areas receiving more than $400 \mathrm{~mm}$ of annual precipitation 3 . Despite its robustness, this tree is subject to many factors including degradation, for some time, that of parasitic insects that mostly is fatal. In Algeria the most important damage caused by xylophagous are those of Eucalyptus Phoracantha semipunctata F. (Coleoptera, Cerambycidae) ${ }^{4}$. The evaluation of the damage caused by this pest until 1982 in Morocco has affected more than 2 million trees 5 .

This proportion of destruction is relatively lower than that recorded in Tunisia and Algeria ${ }^{6}$.

But since 2000s, an insects was detected on the foliage of $E$. camaldulensis trees: Leptocybe invasa (Hymenoptera: Eulophidae).This wasp is gall inducer and cause damages 
mainly to Eucalyptus seedlings in nurseries and young plantations.

Leptocybe invasa commonly known as blue-gum chalcid is a gall wasp of many Eucalyptus species. The invasive gall wasp, Leptocybe invasa, was described in 2004 and is a devastating pest of Eucalyptus worldwide ${ }^{7}$. The Australian gall wasp, is present in the Mediterranean basin, the Middle East and Africa ${ }^{8}$. It was detected in Italy on Aprostocetus sp, in 2000 910.

In Portugal and Spain in 2003 11, Sanchez, 10 and two years later in Turkey and Iran on E. camaldulensis leaves ${ }^{12-13}$. In December 2005, it was detected in the South of France ${ }^{14}$. In Algeria, this pest was added at the alert list by the OEPP in $2006^{15}$

The lytokousparthenogenetic reproduction is typical of $L$. invasa female, 1.1-1.4 $\mathrm{mm}$ in length ${ }^{8}$. It induces galls on petioles, leaf midribs and young branches of several Eucalyptus species such as E. camaldulensis, E. tereticornis, E. rudis, E. grandis, E. globulus and E. viminalis (Figure 1). Leptocybeinvasa lays eggs in plant tissues causing the formation of galls on the leaf midribs and petioles and on the stem of new shoots, eventually leading to leaf-curling and premature aging of the leaves ${ }^{7}$. Egg overloading might cause death of juvenile shoots, while severe attacks lead to leaf fall, stunted growth and may eventually seriously weaken the tree 7 . Developmental stages of the wasp proceed into the gall of a mean length of $2.1 \mathrm{~mm}{ }^{8}$. Galls taken at the end of May 2007 from E. camaldulensis tree and cut up showed mature larva and nymph stages and in the same day we noted the emergence of the adult 8 , indicated that under laboratory conditions, this wasp lasts 132.6 days from oviposition to adult emergence and may produce two or three generations annually. Intense infestations can lead to deformations of the leaves and young stems and to reduction of tree growth.

\section{MATERIALS AND METHODS}

\section{Study area}

Our study concerns the Algerian North-East region. Four areas were chosen to translate continentality gradient in the region. Beni Aziz is the first area located in north. $\left[36^{\circ} 28^{\prime} \mathrm{N}\right.$ $\left.5^{\circ} 39^{\prime} \mathrm{W}\right]$, in the bioclimatical sub-humid with warm winter (precipitation of $700 \mathrm{~mm}$ / year), the other three areas, Setif

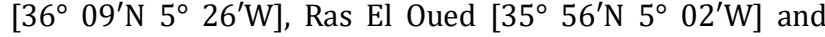
Zrazria $\left[35^{\circ} 53^{\prime} \mathrm{N} 4^{\circ} 42^{\prime} \mathrm{W}\right]$, are located in the semi-arid with temperate winter, and receive respectively 400,350 and 300 mm of annual precipitation.

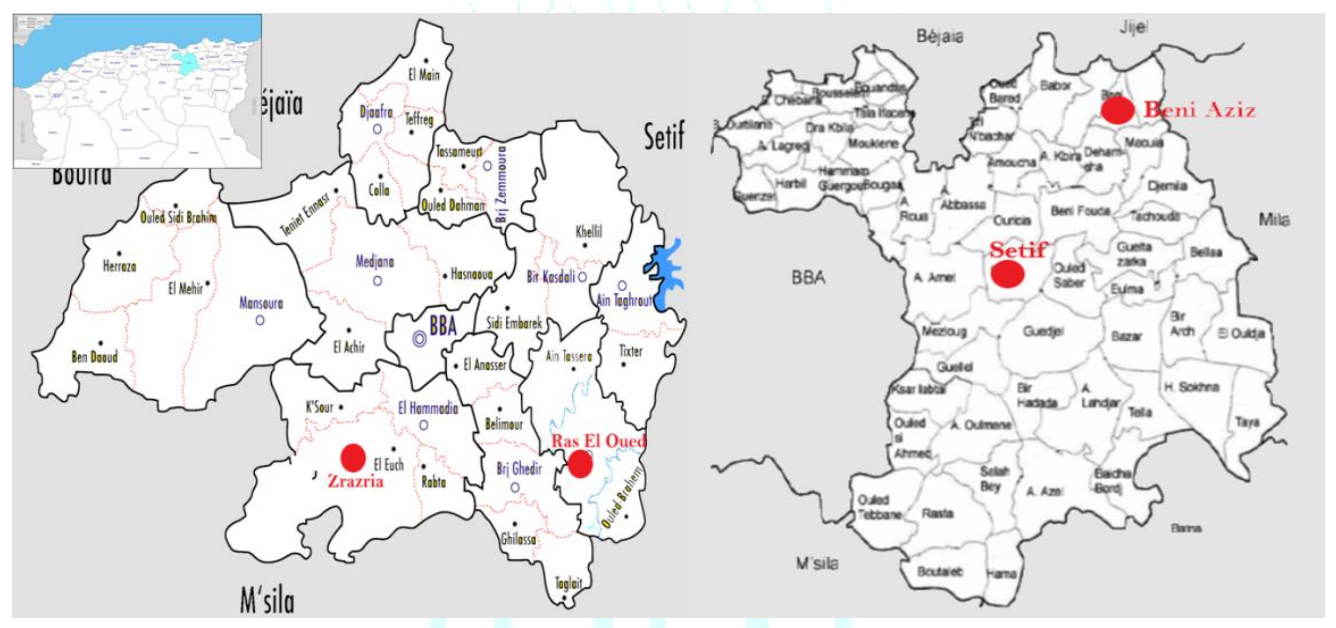

Figure 1 Location map of the study area and sampling sites.

\section{Sampling Method of leaves}

First, after exploration, we selected the most affected trees, second, we organized the samples of each tree, we respected the orientation (North-South-East-West). For each study area 10 trees were marked. 30 leaves of each tree were removed, using a simple materials such Alcohol $\left(70^{\circ}\right.$ ethanol), Cutter, Test tubes, labels, scalpel, pins, collection boxes and marker to count the galls, so it is 300 leaves for each site, which were analyzed. This study is based on the number of galls observed, on both sides of the leaves. In order to highlight the degree of attack of pests. The outputs were made from October 2012 to October 2013, due to one output per month.

\section{Statistical study}

We used the method of time series that connects the time with the number of galls. $(Y=a X+b)$ is a linear function determines the relationship between two variables one is dependent ( $Y=$ number of galls) and the other is independent variable $(X=$ time $)$

The statistical study which deals with the number of galls caused by Leptocybe invasa allowed us to obtain the following results (Table 1).

Table 1: Statistical results.

\begin{tabular}{lccc}
\hline $\begin{array}{l}\text { Leptocybe invasa } \\
\text { Study areas }\end{array}$ & $\begin{array}{c}\text { Total number of } \\
\text { galls }\end{array}$ & $\begin{array}{c}\text { Total average } \\
\text { (galls / leaf) }\end{array}$ & $\begin{array}{c}\text { Total average } \\
\text { (galls / tree) }\end{array}$ \\
\hline Zrazria & 50889 & 6.785 & 203.556 \\
\hline Ras El Oued & 30993 & 4.132 & 123.972 \\
\hline Setif & 14333 & 1.91 & 57.332 \\
\hline Beni Aziz & 11217 & 1.4956 & 44.868 \\
\hline
\end{tabular}


Representing the results as graphs in relation to time (time series) and for each region the following curves (Figure 2).
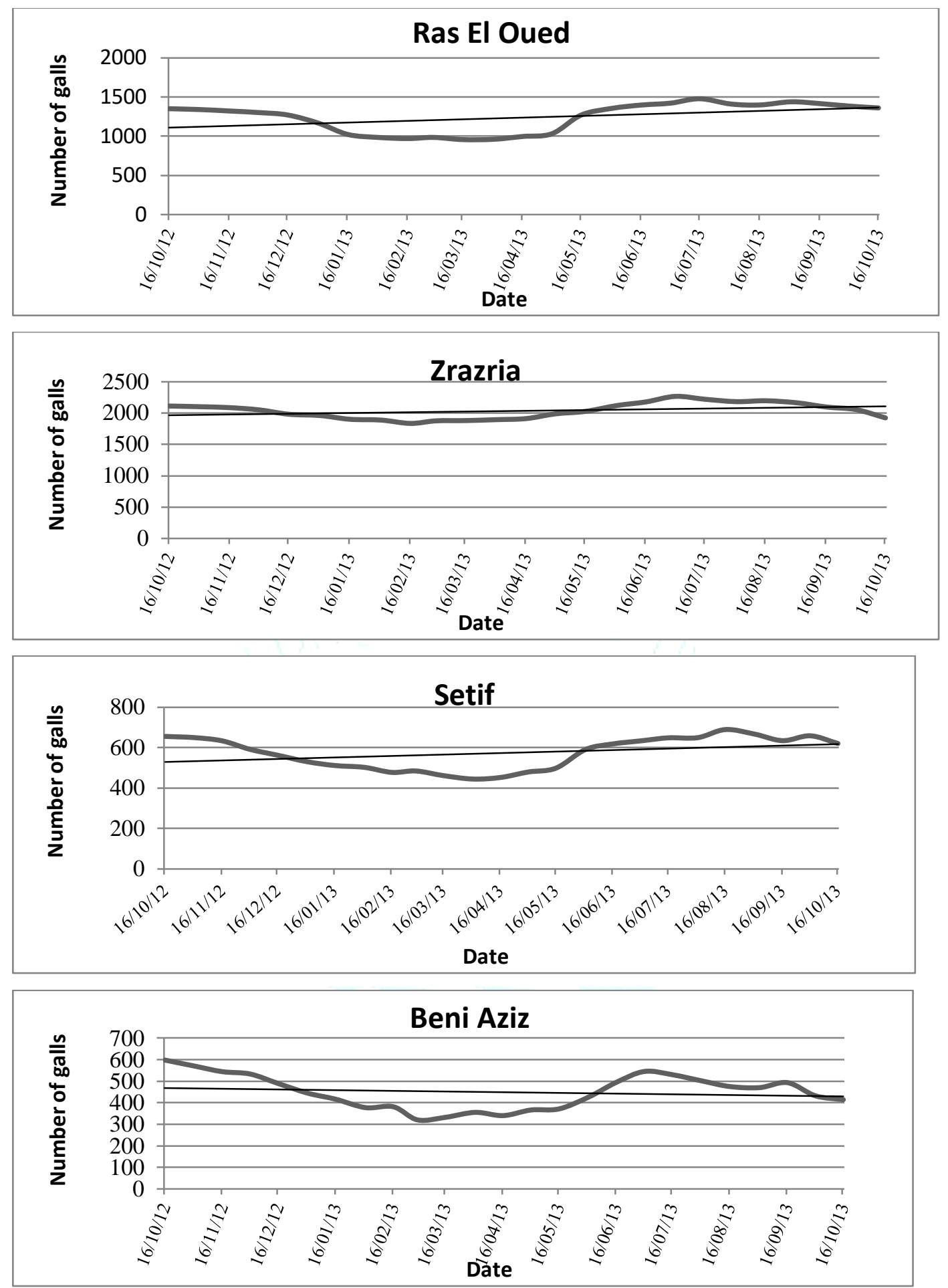

Figure 2: Chronology of the growth of galls Leptocybe invasa of four areas.

The figure 2 shows the variation in the number of galls Leptocybe invasa. According to the graphs obtained for each area, we notice that the number of galls increases in Zrazria and decreases in Beni Aziz. But for the four areas of growth starts in spring and continues almost throughout the summer period.

\section{RESULTS AND DISCUSSION}

The highest Infestations of galls were recorded in the region Zrazria ( 50889 galls ) with an average of ( 6.785 galls / leaf) and ( 203556 galls / tree) , followed by Ras El Oued ( 30993 galls ) with an average of ( 4.132 galls / leaf) and ( 123972 galls / tree) , Setif ( 14333 galls ) with an average of ( 1.91 galls / leaf ) and ( 57,332 gall / tree ) and Beni Aziz ( 11217 galls ) with an average of ( 1.4956 galls / leaf ) and ( 44,868 gall / tree).

These results correspond to the precipitation gradient from the driest area to the wettest. We observe three peaks of many galls (Spring, early Summer, early Autumn), each corresponding to a generation. Autumn and spring show each time a considerable number of galls. The number of galls is not stable throughout the year is Leptocybe invasa because the most affected leaves fall with the damage done 
by the larvae, which suck the sap that nourishes the leaves. The number of galls remains low throughout the cold period because the leaves have fallen and galls have not been renewed by Leptocybe invasa. Strong attacks induce desiccation of leaves and their fall with no cases of tree mortality has been registered

The research done in our four areas, Ras el Oued Zrazria (region of Bordj Bou Arreridj) and Beni Aziz and Setif (region of Setif), from October 2012 to October 2013, were oriented in order to highlight the decline of Eucalyptus camaldulensis. The appearance of deformed leaves and twigs showed us the presence of species of insect gall Leptocybe invasa Hymenoptera: Eulophidae) inducing galls on the midrib and twigs. To highlight the density of galls on trees and measuring the degree of attack by this insect gall. we counted the galls,thus, we took 30 leaves per tree therefore 300 leaves per area.

Infestations of galls Leptocybe invasa, the highest were recorded in the region Zrazria (50889 galls) with an average of ( 6.785 galls / leaf ) and ( 203556 galls / tree), followed by Ras El Oued ( 30993 galls ) with an average of ( 4.132 galls / leaf ) and (123972 galls / tree) , Setif ( 14333 galls ) with an average of ( 1.91 galls / leaf ) and (57,332 gall / tree ) and Beni Aziz ( 11217 galls ) with an average of ( 1.4956 galls / leaf ) and ( 44,868 gall / tree).

Developmental stages of the wasp proceed into the gall of an average length of $2.1 \mathrm{~mm}$ [8], opened Galls in July 2013 have shown enclose mature larva and nymph stages; In the same day we saw the emergence of the adult.

Maatouf and Lumaret 16, who did a research on adult emergence of Leptocybe invasain 2012, the emergence is not stable throughout the year and starts at Spring and continues throughout the hot and dry period until Autumn.

\section{CONCLUSIONS}

Eucalyptus camaldulensis is $95 \%$ in Algeria coverage. This resistant tree is still a matter of many degradation factors including those of insects.

Invasive species reported in Eucalyptus is becoming more numerous and are demonstrated considerable ability to multiply. Sometimes after a very short period of time, they are able to colonize many states, resulting in a real danger regarding to these trees in heavy infestations.

Our main objective was to try to make a statistical study by counting galls of Leptocybe invasa galls on leaves of Eucalyptus camaldulensis. And this study has allowed us to know the damage rate Leptocybe invasa.

The statistical analysis of the results allows us to observe three peaks of many galls (Spring, early Summer, early Autumn), corresponding to the precipitation gradient from the driest area to the wettest.

Currently, no control measures available against this species and more cautions are needed when there is exchange of eucalyptus seedlings for planting. Improving the level of oversight is necessary and we must conduct research in arboretums to identify species of Eucalyptus that resist this wasp.

Acknowledgments: This study was done with the help of work of Maatouf and Lumaret (2012), their research has inspired us a lot, to do this study.

\section{REFERENCES}

[1] Lamprecht H. 1990. Silviculture in the Tropics: tropical forest ecosystems and their tree species-possibilities and methods for their long-term utilization. GTZ, Eschborn. Germany. 296p.

[2] FA0, 2000. Food and Agriculture Organization., Global forest resource assessment, main report. Dans Forestry paper.

[3] Bensaid S., Hamimi S., et Tabti W. La question du reboisement en Algérie. Cahiers Sécheresse., 1998; 9(1):5-11.

FAO, 1986. Programme des Nations Unies pour le Développement., Food and Agriculture Organization., Rapport intérimaire Algérie. Projet PNUD/ALG/83/013., 26.

[5] Cadahia D. Importance des insectes ravageurs de l'eucalyptus en région méditerranéenne. Bult. OEPP/ЕPPOB., 1986 16:265-283.

[6] El Yousfi, M. 1986. Le Phoracantha semipunctata au Maroc, écologie et méthode de lutte. note Technique de la Division de Recherche et d'Expérimentation forestière. Direction des Eaux et Forêts, Rabat, Maroc.

[7] Mendel Z., Protasov A., and Fisher N. Taxonomy and biology of Leptocybeinvasa gen. and sp. n. (Hymenoptera: Eulophidae) an invasive gall inducer on Eucalyptus. Aust J Entomol., 2004; 43:101-113.

[8] Mendel Z., Protasov A., Blumberg D., Brand D., Saphir, N, Madar Z., and La Salle J. Release and recovery of parasitoids of the Eucalyptus gall wasp Ophelimusmaskelli in Israel. Phytoparasitica., 2007; 35:330-332.

[9] Bella S. and Lo Verde G. Presenzanell'Italia Continentale e in Sicilia di Ophelimusprope eucalypti (Gahan) e Aprostocetussp., galligenidegliEucalipti (Hymenoptera Eulophidae). Naturalista Sicil. S. IV., 2002; 26:191-197.

[10] Sanchez, I. Descubiertas dos nuevas plagas del eucalipto en España. Quercus., 2003; 214:32-33.

[11] Branco M., Boavida C., Durand N., Franco J. C., and Mendel Z. Presence of the Eucalyptus gall wasp Ophelimusmaskelli and its parasitoid Closteroceruschamaeleon in Portugal : First record, geographic distribution and host preference. Phytoparasitica., 2009; 37:51-54

[12] Doganlar 0. Occurrence of Leptocybeinvasa Fisher \& La Salle, (Hymenoptera: Chalcidoidea) on Eucalyptus camaldulensis in Turkey, with a description of the male sex. Zool. Middle East. 2005; 35:112-114.

[13] Hesami S., Alemansoor H., and Seyedebrahimi, S. Report of Leptocybeinvasa (Hym. : Eulophidae), gall wasp of Eucalyptus camaldulensis with notes on biology in Shiraz vicinity. J. Entomol. Soc. Iran., 2005; 24:99-108.

[14] EMPPO, 2006a. European and Mediterranean Plant Protection Organization., First report of two new Eucalyptus pests in the south of France :Ophelimusmaskelliand Leptocybeinvasa Reporting Service., 2006; 9(9).

[15] EMPPO, 2006b. European and Mediterranean Plant Protection Organization., Addition of Leptocybeinvasa to the alert list. EMPPO Reporting Service., 2006; 9(10).

[16] Maatouf N., et Lumaret J. P. Eco-ethologie des nouveaux ravageurs invasifs des Eucalyptus du Maroc. Ann. Soc. entomol. Fr. (n.s.)., 2012; 48(3-4):289-297. 